\title{
Sårbare barn
}

\section{Barn født av kvinner under legemiddelassistert rehabilitering har mer problemer knyttet til oppmerksomhet, finmotorikk og arbeidsminne.}

I løpet av de siste årene har antallet opioidbrukere som mottar legemiddelassistert rehabilitering (LAR), økt betydelig i Norge. Som et resultat blir et økende antall barn prenatalt eksponert for opioider som metadon eller buprenorfin.

I sin doktorgradsavhandling ved Senter for rus- og avhengighetsforskning og Enheten for kognitiv utviklingspsykologi, Psykologisk institutt, har stipendiat Carolien Konijnenberg undersøkt kognitive ferdigheter hos barn av kvinner som har brukt metadon eller buprenorfin (Subutex) i svangerskapet. Disse barna har hun sammenliknet med barn av kvinner som ikke har brukt LAR-medikamenter eller rusmidler i svangerskapet.

Konijnenberg viser at LAR-barn som er ca. fire år, har flere problemer med å regulere og kontrollere oppmerksomhet, finmotorikk og atferd enn barn som ikke er blitt eksponert for legemiddelassistert rehabilitering eller rus. Ferdigheter er avgjørende for å kunne planlegge, løse problemer og hemme impul- ser og har stor betydning for barns daglige fungering.

- Resultatene viser at barn av mødre i legemiddelassistert rehabilitering er en sårbar gruppe som bør følges opp nøye. Ikke bare i barnets første leveår, men også i tiden etter, sier hun. - Barna har like gode læreevner som barn som ikke har vært eksponert, så det er mye å bygge på for å sikre en positiv utvikling.

Den unike studien i norsk sammenheng er del av et større prosjekt som følger opp en nasjonal gruppe med barn født $\mathrm{i}$ perioden 2005-06 fra fødsel frem til skolealder. Disse barna har vært eksponert for metadon eller Subutex i fosterlivet. Dette er den første norske studien der man undersøker hvordan barn av kvinner i LAR-behandling utvikler seg på lang sikt.

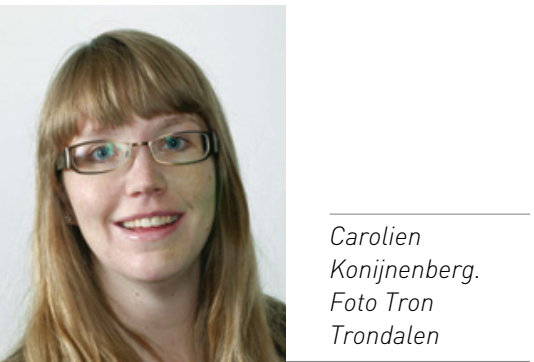

Disputas

Carolien Konijnenberg disputerte for ph.d.graden ved Universitetet i Oslo 15.2. 2013

Tittelen på avhandlingen er A prospective study of the cognitive development of children prenatally exposed to opioid maintenance treatment (OMT).
Tone Bergset

tone.bergset@legeforeningen.no

Tidsskriftet

\section{Kan parasittinfeksjon øke risikoen for hiv?}

\section{Nyere forskning viser at parasitten Schistosoma haematobium kan føre til forandringer i genitale slimhinner som er forenlig med økt risiko for hivinfeksjon.}

Parasittsykdommen schistosomiasis er nesten like vanlig som malaria og rammer millioner som lever under dårlige sanitære forhold uten rent vann. De fleste vet ikke at de er smittet og får ikke tilgang til enkel, forebyggende behandling. Mange smittede bor i områder som også er hardt rammet av hivepidemien, og studier har antydet en sammenheng mellom kvinnelig genital schistosomiasis og hiv. Mulige mekanismer for dette har hittil ikke vært kjent.

Jourdan har i doktorgradsavhandlingen Schistosoma haematobium infection in the female genital mucosa undersøkt immunfarget snitt av biopsier fra genital slimhinne fra kvinner med schistosomiasis og funnet økt antall målceller for hiv, CD4+ T-lymfocytter og makrofager rundt parasitteggene. Parasittinfisert vev har også større tetthet av blodkar enn i vev fra friske kvinner, noe som sannsynligvis gir slimhinneblødning og redusert barriere mot hiv. Videre har Jourdan og medarbeidere utviklet en enkel metode for å analysere vevsprøver med tanke på parasitter og andre forsømte sykdommer i utviklingsland.

Behandling av schistosomiasis består av en enkelt tablettdose som er rimelig og godt tolerert. Verdens helseorganisasjon anbefaler årlig behandling av alle innbyggere i høyendemiske områder, men grunnet økonomiske og logistiske begrensninger er det få som behandles. I videre forskning vil man se nærmere på om behandling av schistosomiasis kan redusere kvinnelig genital schistosomiasis og om dette derved kan bidra til å bremse hivepidemien.

\section{Hanne Støre Valeur}

hanne.store.valeur@legeforeningen.no

Tidsskriftet

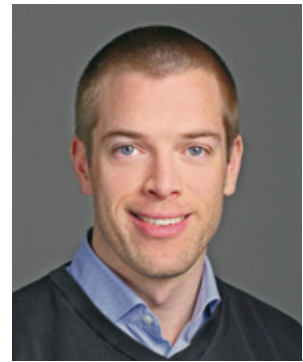

Peter Mark Jourdan. Foto Håvard Storvestre, BA fotografene
Disputas

Peter Mark Jourdan disputerte for ph.d.graden ved Universitetet i Oslo 7.2. 2013 Tittelen på avhandlingen er Schistosoma haematobium infection in the female genital mucosa. Immunohistochemical and clinicopathological analyses with respect to HIV target cells and vascularity in cervicovaginal tissue. Crosssectional studies in Malawi and Madagascar. 